\title{
Palladium(II) complexes bearing a salicylaldiminato ligand with a hydroxyl group: Synthesis, structures, deprotonation, and catalysis
}

\section{$\operatorname{AUTHOR}(S):$}

Murata, Yusuke; Ohgi, Hiroyuki; Fujihara, Tetsuaki; Terao, Jun; Tsuji, Yasushi

\section{CITATION:}

Murata, Yusuke ... [et al]. Palladium(II) complexes bearing a salicylaldiminato ligand with a hydroxyl group: Synthesis, structures, deprotonation, and catalysis. Inorganica Chimica Acta 2011, 368(1): 237-241

\section{ISSUE DATE:}

2011-03

URL:

http://hdl.handle.net/2433/157346

\section{RIGHT:}

(c) 2010 Elsevier B.V.; この論文は出版社版でありません。引用の際には 出版社版をご確認ご利用ください。; This is not the published version. Please cite only the published version. 
Palladium(II) complexes bearing a salicylaldiminato ligand with a hydroxyl group: synthesis, structures, deprotonation, and catalysis.

\title{
Yusuke Murata, ${ }^{\text {a,b }}$ Hiroyuki Ohgi, ${ }^{a}$ Tetsuaki Fujihara,b Jun Terao, ${ }^{b}$ and Yasushi Tsuji*b
}

a Kurashiki Research Laboratories, KURARAY CO., LTD., 2045-1 Sakazu, Kurashiki, Okayama 710-0801, Japan. FAX +81-86-423-4581

$b \quad$ Department of Energy and Hydrocarbon Chemistry, Graduate School of Engineering, Kyoto University, Kyoto 615-8510, Japan. FAX: +81-75-383-2514. E-mail: ytsuji@scl.kyoto-u.ac.jp

\begin{abstract}
Palladium complexes with a salicylaldiminato ligand bearing a hydroxyl group (1a and $\mathbf{1 b})$ have been synthesized and characterized. The structures of these complexes were confirmed by X-ray crystallography. A reversible deprotonation/protonation of the hydroxyl moiety on $\mathbf{1 b}$ was observed, while such behaviour was impossible with a related palladium complex (1c) bearing a methoxyl group in place of the hydroxyl group. The deprotonation affected its catalytic behaviour: the activity for polymerization of methyl acrylate catalyzed by $\mathbf{1 b}$ considerably decreased in the presence of 1 equiv of ${ }^{t} \mathrm{BuOK}$.
\end{abstract}

\section{Key Word}

palladium, salicylaldiminato ligand, acid-base behaviour, crystal structures, polymerization 


\section{Introduction}

Much attention has been paid to transition-metal-catalyzed polymerization catalysts bearing salicylaldiminato ligands since both electronic and steric parameters of the ligands can be systematically tunable by introducing various substituents on the aromatic ring [1]. Among them, palladium complexes bearing the salicylaldiminato ligands were investigated as catalysts for polymerization of methyl acrylate, acrylonitrile, and norbornene [1n, 2]. Meanwhile, introduction of a hydroxyl group onto the aromatic ring is promising because electronic nature might be regulated by simple deprotonation/protonation procedures. Actually, catalytic activity can be controlled in the presence/absence of protons on ligands [3].

We anticipated that a salicylaldimiato ligand bearing a hydroxyl group would control the catalytic activity in the presence/absence of the proton near a metal center. In the present study, we designed and synthesized palladium complexes with a salicylaldiminato ligand having a hydroxyl functionality. The structures of these complexes were unambiguously determined by $\mathrm{X}$-ray crystallography. Deprotonation of the hydroxyl group affected the electronic nature of the complex as well as catalytic activity for polymerization of methyl acrylate.

\section{Experimetal}

\subsection{General procedure}

All manipulations were performed under an argon atmosphere using standard Schlenk-type glasswares on a dual-manifold Schlenk line. Unless otherwise noted, materials obtained from commercial suppliers were used without further purification. THF, $\mathrm{CH}_{2} \mathrm{Cl}_{2}$ and methyl acrylate were dried and purified before use by usual methods [4]. ${ }^{1} \mathrm{H},{ }^{13} \mathrm{C}\left\{{ }^{1} \mathrm{H}\right\}$ and ${ }^{31} \mathrm{P}\left\{{ }^{1} \mathrm{H}\right\}$ NMR spectra were measured with a JEOL ECX-400P spectrometer. The ${ }^{1} \mathrm{H}$ NMR chemical shifts are reported relative to tetramethylsilane (TMS, $0.00 \mathrm{ppm}$ ). The ${ }^{13} \mathrm{C}$ NMR chemical shifts are reported relative to $\mathrm{CDCl}_{3}(77.0 \mathrm{ppm})$. The ${ }^{31} \mathrm{P}$ NMR chemical shifts are reported relative to $85 \% \mathrm{H}_{3} \mathrm{PO}_{4}(0.00 \mathrm{ppm})$ as an external standard. Analytical size-exclusion chromatography (SEC) was performed using $\mathrm{CHCl}_{3}$ as the eluent at a flow rate of $1.0 \mathrm{~mL} / \mathrm{min}$ on an HPLC (Shimadzu) equipped with a LC-10AT HPLC pump, a RID-10A RI detector through a column set consisting of Shodex $-\mathrm{K}-601 \mathrm{~L}(0.8 \times 30 \mathrm{~cm} \times 2)$. Average molecular weights $(M \mathrm{n})$ and the polydisperse index (PDI) of poly(methyl acrylate) were determined by using polystyrene standards. Electron spray ionization time-of-flight mass spectrometry (ESI-TOF mass) was carried out on a waters LCT-Premier instrument. The sprayer was held at a potential of $+2.6 \mathrm{kV}$ in the positive detection mode or $-2.8 \mathrm{kV}$ in the negative detection mode. The orifice potential was maintained at $50 \mathrm{~V}$ in each detection modes. Elemental 
analysis was carried out at Center for Organic Elemental Microanalysis, Graduate School of Pharmaceutical Science, Kyoto University. TLC analyses were performed on commercial glass plates bearing a $0.25-\mathrm{mm}$ layer of Merck Silica gel 60F254. $N$-(2,6-Diisopropylphenyl)-3-hydroxysalicylaldimine $\left(\mathrm{HL}^{\mathrm{OH}}\right)$ [1e], $N$-(2,6-diisopropylphenyl)-3-methoxysalicylaldimine $\left(\mathrm{HL}^{\mathrm{OMe}}\right)$ [1e], cis(1,5-cyclooctadiene)dichloropalladium $\left[\mathrm{PdCl}_{2}(\mathrm{cod})\right]$ [5], and cis(1,5-cyclooctadiene)chloromethylpalladium [PdClMe(cod)] [6] were also prepared according to literature procedures.

\subsection{Synthesis of palladium complexes}

\subsubsection{Synthesis of $\mathrm{PdCl}\left(\mathrm{PPh}_{3}\right)\left(\mathrm{L}^{\mathrm{OH}}\right)(\mathbf{1 a})$}

To a solution of $\mathrm{N}$-(2,6-diisopropylphenyl)-3-hydroxysalicylaldimine ( $\left.\mathrm{HL}^{\mathrm{OH}}, 0.40 \mathrm{~g}, 1.4 \mathrm{mmol}\right)$ in THF (5.0 mL) was added a solution of ${ }^{t} \mathrm{BuOK}(1.0 \mathrm{M}$ in THF, $2.8 \mathrm{~mL}, 2.8 \mathrm{mmol})$ at room temperature. After stirring for $30 \mathrm{~min}$, all volatiles were removed in vacuo. The resulting solid residue was dissolved in dichloromethane $(5.0 \mathrm{~mL})$ and then $\mathrm{PdCl}_{2}(\mathrm{cod})(0.38 \mathrm{~g}, 1.33 \mathrm{mmol})$ and $\mathrm{PPh}_{3}(0.35 \mathrm{~g}, 1.3 \mathrm{mmol})$ were added to the solution. After stirring at room temperature overnight, triethylammonium hydrogen chloride $(0.20 \mathrm{~g}, 1.5 \mathrm{mmol})$ was added. The reaction mixture was stirred for additional $30 \mathrm{~min}$ and then filtered. Removal of all volatiles in vacuo gave crude products as yellow solids. Recrystallization from dichloromethane/hexane afforded 1a as yellow crystals. Yield $0.63 \mathrm{~g}(68 \%) .{ }^{1} \mathrm{H}$ NMR $\left(\mathrm{CDCl}_{3}\right): \delta 7.86\left(\mathrm{~d},{ }^{4} J_{\mathrm{PH}}=13.4 \mathrm{~Hz}, 1 \mathrm{H}\right.$, $\operatorname{ArN}=\mathrm{CH})$, 7.8-7.7 (m, 6H, Ar(phosphine)), 7.6-7.5 (m, 3H, $\operatorname{Ar}($ phosphine)), 7.5-7.4 (m, 6H, $\operatorname{Ar}\left(\right.$ phosphine)), 7.2-7.1 (m, 3H, N-Ar), $6.80\left(\mathrm{dd},{ }^{3} J_{\mathrm{HH}}=7.44 \mathrm{~Hz},{ }^{4} J_{\mathrm{HH}}=1.49 \mathrm{~Hz}, 1 \mathrm{H}, \mathrm{Ar}\right), 6.74$ $\left(\mathrm{dd},{ }^{3} J_{\mathrm{HH}}=7.93 \mathrm{~Hz},{ }^{4} J_{\mathrm{HH}}=1.49 \mathrm{~Hz}, 1 \mathrm{H}, \mathrm{Ar}\right), 6.50\left(\mathrm{t},{ }^{3} J_{\mathrm{HH}}=7.93 \mathrm{~Hz}, 1 \mathrm{H}, \mathrm{Ar}\right), 4.99(\mathrm{~s}, 1 \mathrm{H}, \mathrm{OH})$, $3.45\left(\mathrm{sep},{ }^{3} J_{\mathrm{HH}}=6.94 \mathrm{~Hz}, 2 \mathrm{H}, \mathrm{CH}\left(\mathrm{CH}_{3}\right)_{2}\right), 1.40\left(\mathrm{~d},{ }^{3} J_{\mathrm{HH}}=6.94 \mathrm{~Hz}, 6 \mathrm{H}, \mathrm{CH}\left(\mathrm{CH}_{3}\right)_{2}\right), 1.15(\mathrm{~d}$, $\left.{ }^{3} J_{\mathrm{HH}}=6.94 \mathrm{~Hz}, 6 \mathrm{H}, \mathrm{CH}\left(\mathrm{CH}_{3}\right)_{2}\right) \cdot{ }^{13} \mathrm{C}\left\{{ }^{1} \mathrm{H}\right\} \mathrm{NMR}\left(\mathrm{CDCl}_{3}\right): \delta 163.3,152.5,147.7,146.9,141.3$, 135.0, 134.8, 131.2, 131.1, 129.0, 128.6, 128.4, 128.3, 126.7, 125.1, 122.9, 118.0, 116.0, 115.6, 28.7, 24.6, 22.9. ${ }^{31} \mathrm{P}\left\{{ }^{1} \mathrm{H}\right\} \mathrm{NMR}\left(\mathrm{CDCl}_{3}\right): \delta 30.5$. ESI-TOF mass (in the negative mode, $\left.\mathrm{MeOH}\right)$, $m / z 698.2\left([1 \mathbf{a}-\mathrm{H}]^{-} ; I=100 \%\right.$ in the range of $\left.m / z, 100-2000\right)$. Anal. Calcd for $\mathrm{C}_{37} \mathrm{H}_{37} \mathrm{ClNO}_{2} \mathrm{PPd}$ : C 63.44, H 5.32, N 2.00. Found: C 63.37, H 5.43, N 1.91\%.

\subsubsection{Synthesis of $\mathrm{PdMe}\left(\mathrm{PPh}_{3}\right)\left(\mathrm{L}^{\mathrm{OH}}\right)(\mathbf{1 b})$}

The complex was synthesized with $\mathrm{PdClMe}(\mathrm{cod})(0.35 \mathrm{~g}, 1.3 \mathrm{mmol})$ instead of $\mathrm{PdCl}_{2}(\mathrm{cod})$ by the method similar to that used for 1a. Yield $0.82 \mathrm{~g}(91 \%) .{ }^{1} \mathrm{H}$ NMR $\left(\mathrm{CDCl}_{3}\right): \delta 7.99\left(\mathrm{~d},{ }^{4} \mathrm{~J}_{\mathrm{PH}}=\right.$ 
11.4 Hz, 1H, ArN=CH), 7.7-7.5 (m, 6H, Ar(phosphine)), 7.5-7.3 (m, 9H, Ar(phosphine)), 7.2 $(\mathrm{m}, 3 \mathrm{H}, \mathrm{N}-\mathrm{Ar}), 6.78\left(\mathrm{dd},{ }^{3} J_{\mathrm{HH}}=7.44 \mathrm{~Hz},{ }^{4} J_{\mathrm{HH}}=1.49 \mathrm{~Hz}, 1 \mathrm{H}, \mathrm{Ar}\right), 6.64\left(\mathrm{dd},{ }^{3} J_{\mathrm{HH}}=8.43 \mathrm{~Hz}\right.$, $\left.{ }^{4} J_{\mathrm{HH}}=1.49 \mathrm{~Hz}, 1 \mathrm{H}, \mathrm{Ar}\right), 6.34\left(\mathrm{dd},{ }^{3} J_{\mathrm{HH}}=7.44 \mathrm{~Hz},{ }^{3} J_{\mathrm{HH}}=8.43 \mathrm{~Hz}, 1 \mathrm{H}, \mathrm{Ar}\right), 5.76(\mathrm{~s}, 1 \mathrm{H}, \mathrm{OH}), 3.46$ (sep, $\left.{ }^{3} J_{\mathrm{HH}}=6.94 \mathrm{~Hz}, 2 \mathrm{H}, \mathrm{CH}\left(\mathrm{CH}_{3}\right)_{2}\right), 1.34\left(\mathrm{~d},{ }^{3} J_{\mathrm{HH}}=6.94 \mathrm{~Hz}, 6 \mathrm{H}, \mathrm{CH}\left(\mathrm{CH}_{3}\right)_{2}\right), 1.13\left(\mathrm{~d},{ }^{3} J_{\mathrm{HH}}=\right.$ $\left.6.94 \mathrm{~Hz}, 6 \mathrm{H}, \mathrm{CH}\left(\mathrm{CH}_{3}\right)_{2}\right),-0.35\left(\mathrm{~d},{ }^{3} J_{\mathrm{PH}}=2.98 \mathrm{~Hz}, 3 \mathrm{H}, \mathrm{Pd}-\mathrm{CH}_{3}\right) .{ }^{13} \mathrm{C}\left\{{ }^{1} \mathrm{H}\right\} \mathrm{NMR}\left(\mathrm{CDCl}_{3}\right): \delta$ $165.8,156.9,149.1,147.3,140.9,134.7,134.5,131.0,130.6,130.9,130.3,128.4,128.3,126.2$, $125.2,123.3,117.0,113.8,113.1,28.0,25.1,22.5,0.19\left(\mathrm{~d},{ }^{2} J_{\mathrm{cp}}=11.2 \mathrm{~Hz}, \mathrm{Pd}-C_{3}\right) .{ }^{31} \mathrm{P}\left\{{ }^{1} \mathrm{H}\right\}$ NMR $\left(\mathrm{CDCl}_{3}\right): \delta 43.32$. ESI-TOF mass (in the negative mode, $\left.\mathrm{MeOH}\right), m / z 678.2\left([\mathbf{1 b}-\mathrm{H}]^{-} ; I\right.$ $=100 \%$ in the range of $m / z, 100-2000)$. Anal. Calcd for $\mathrm{C}_{38} \mathrm{H}_{40} \mathrm{NO}_{2} \mathrm{PPd}$ : C 67.11, H 5.93, N 2.06. Found: C 67.05, H 5.97, N 2.09\%.

\subsubsection{Synthesis of $\mathrm{PdMe}\left(\mathrm{PPh}_{3}\right)\left(\mathrm{L}^{\mathrm{OMe}}\right)(\mathbf{1 c})$}

To a solution of $\mathrm{N}$-(2,6-diisopropylphenyl)-3-methoxysalicylaldimine ( $\mathrm{HL}^{\mathrm{OMe}}, 0.42 \mathrm{~g}, 1.4$ mmol) in THF (5.0 mL) was added a solution of ${ }^{t} \mathrm{BuOK}(1.0 \mathrm{M}$ in THF, $1.4 \mathrm{~mL}, 1.4 \mathrm{mmol})$ at room temperature. After stirring for $30 \mathrm{~min}$, all volatiles were removed in vacuo. The resulting solid residue was dissolved in dichloromethane $(5.0 \mathrm{~mL})$, and then $\mathrm{PdClMe}(\mathrm{cod})(0.35 \mathrm{~g}, 1.3$ mmol $)$ and $\mathrm{PPh}_{3}(0.35 \mathrm{~g}, 1.3 \mathrm{mmol})$ were added to the solution. After stirring at room temperature overnight, all volatiles were removed in vacuo. The resulting crude products were purified by recrystallization from dichloromethane/hexane afforded 1c as yellow crystals. Yield $0.79 \mathrm{~g}(86 \%) .{ }^{1} \mathrm{H} \mathrm{NMR}\left(\mathrm{CDCl}_{3}\right): \delta 7.97\left(\mathrm{~d},{ }^{4} J_{\mathrm{PH}}=11.4 \mathrm{~Hz}, 1 \mathrm{H}, \mathrm{ArN}=\mathrm{CH}\right), 7.7-7.6(\mathrm{~m}, 6 \mathrm{H}$, $\operatorname{Ar}\left(\right.$ phosphine)), 7.5-7.3 (m, 9H, Ar(phosphine)), 7.2 (m, 3H, N-Ar), $6.73\left(\mathrm{~d},{ }^{3} J_{\mathrm{HH}}=7.44 \mathrm{~Hz}, 1 \mathrm{H}\right.$, Ar), $6.72\left(\mathrm{~d},{ }^{3} J_{\mathrm{HH}}=8.43 \mathrm{~Hz}, 1 \mathrm{H}, \mathrm{Ar}\right), 6.36\left(\mathrm{t},{ }^{3} J_{\mathrm{HH}}=7.93 \mathrm{~Hz}, 1 \mathrm{H}, \mathrm{Ar}\right), 3.67\left(\mathrm{~s}, 3 \mathrm{H}, \mathrm{OCH}_{3}\right), 3.52$ (sep, $\left.{ }^{3} J_{\mathrm{HH}}=6.94 \mathrm{~Hz}, 2 \mathrm{H}, \mathrm{CH}\left(\mathrm{CH}_{3}\right)_{2}\right), 1.29\left(\mathrm{~d},{ }^{3} J_{\mathrm{HH}}=6.94 \mathrm{~Hz}, 6 \mathrm{H}, \mathrm{CH}\left(\mathrm{CH}_{3}\right)_{2}\right), 1.11\left(\mathrm{~d},{ }^{3} J_{\mathrm{HH}}=6.94\right.$ $\left.\mathrm{Hz}, 6 \mathrm{H}, \mathrm{CH}\left(\mathrm{CH}_{3}\right)_{2}\right),-0.45\left(\mathrm{~d},{ }^{3} \mathrm{~J}_{\mathrm{PH}}=2.53 \mathrm{~Hz}, 3 \mathrm{H}, \mathrm{Pd}-\mathrm{CH}_{3}\right) .{ }^{13} \mathrm{C}\left\{{ }^{1} \mathrm{H}\right\} \mathrm{NMR}\left(\mathrm{CDCl}_{3}\right): \delta 165.6$, 160.5, 152.9, 147.7, 141.1, 135.0, 134.9, 131.9, 131.2, 130.1, 130.0, 128.1, 128.0, 127.2, 126.0, $123.2,118.7,113.2,111.7,55.4,27.9,25.0,22.5,1.79\left(\mathrm{~d},{ }^{2} J_{\mathrm{cp}}=11.2 \mathrm{~Hz}, \mathrm{Pd}-C_{3}\right) .{ }^{31} \mathrm{P}\left\{{ }^{1} \mathrm{H}\right\}$ $\operatorname{NMR}\left(\mathrm{CDCl}_{3}\right): \delta$ 35.9. ESI-TOF mass (in the positive mode, $\left.\mathrm{MeOH}\right), \mathrm{m} / z 716.2\left([\mathbf{1 c}+\mathrm{Na}]^{+} ; I\right.$ $=100 \%$ in the range of $m / z, 100-2000$ ). Anal. Calcd for $\mathrm{C}_{39} \mathrm{H}_{42} \mathrm{NO}_{2} \mathrm{PPd} \cdot 0.5 \mathrm{H}_{2} \mathrm{O}: \mathrm{C} 66.62, \mathrm{H}$ 6.16, N 1.99. Found: C 66.63, H 6.18, N 1.93\%.

\subsection{General procedure for polymerization}

In a glove box under a nitrogen atmosphere, a $20 \mathrm{~mL}$ Schlenk flask was charged with $1(0.011$ $\mathrm{mmol})$, THF $(0.30 \mathrm{~mL})$ and dichloromethane $(3.6 \mathrm{~mL})$. In the case of the addition of ${ }^{t} \mathrm{BuOK}$ 
(1.0 $\mathrm{M}$ in THF, $11 \mu \mathrm{L}, 0.011 \mathrm{mmol}$ ), the base was added before charging dichloromethane. After methyl acrylate $(1.0 \mathrm{~mL}, 12 \mathrm{mmol})$ was introduced to the flask, the reaction mixture was stirred at the ambient temperature for $24 \mathrm{~h}$. The reaction mixture was poured into $50 \mathrm{~mL}$ of methanol and precipitated polymers were collected by filtration and dried under vacuum at $60{ }^{\circ} \mathrm{C}$ for $24 \mathrm{~h}$. Average molecular weights $(\mathrm{Mn})$ and the polydisperse index (PDI) of poly(methyl acrylate) were determined using polystyrene standards.

\subsection{X-ray crystallography}

A summary of crystal structure refinements of 1a-1c was given in Table 1. Data were collected on a Rigaku/Saturn70 CCD diffractometer using graphite-monochromated Mo K $\alpha$ radiation ( $\lambda$ $=0.71070 \AA$ ) at $153 \mathrm{~K}$, and processed using CrystalClear (Rigaku) [7]. The structures were solved by a direct method and refined by full-matrix least-square refinement on $F^{2}$. The non-hydrogen atoms were refined anisotropically. All hydrogen atoms were located on the calculated positions and not refined. All calculations were performed using the CrystalStructure software package [8].

\section{Results and Discussion}

3.1. Synthesis and structure of palladium complexes

A ligand precursor $\left(\mathrm{HL}^{\mathrm{OH}}\right)$ was readily prepared by the reaction of 2,3-dihydroxybenzaldehyde with 2,6-diisopropylaniline in methanol [1e]. Palladium complexes with a salicylaldiminato ligand bearing a hydroxyl group $\left(\mathrm{L}^{\mathrm{OH}}\right)$ were synthesized as shown in Scheme 1. First, the reaction of the ligand precursor with 2 equiv of ${ }^{t} \mathrm{BuOK}$ afforded a dianionic intermediate in situ. Then, addition of $\mathrm{PdCl}(\mathrm{X})(\operatorname{cod})(\mathrm{X}=\mathrm{Cl}$ or $=\mathrm{Me})$ and $\mathrm{PPh}_{3}$ in $\mathrm{CH}_{2} \mathrm{Cl}_{2}$ followed by the treatment of $\mathrm{Et}_{3} \mathrm{~N} \cdot \mathrm{HCl}$ afforded $\mathrm{PdX}\left(\mathrm{PPh}_{3}\right)\left(\mathrm{L}^{\mathrm{OH}}\right)(\mathrm{X}=\mathrm{Cl}$ (1a) or $=\mathrm{Me}(\mathbf{1 b}))$ in good yields. For comparison, a related palladium complex with a salicylaldiminato ligand bearing a methoxyl group $\left(\mathrm{L}^{\mathrm{OMe}}\right), \mathrm{PdMe}\left(\mathrm{PPh}_{3}\right)\left(\mathrm{L}^{\mathrm{OMe}}\right)(\mathbf{1 c})$, in place of the hydroxyl group was also synthesized by the reaction of the corresponding salicylaldimine with ${ }^{t} \mathrm{BuOK}$ followed by adding $\mathrm{PdClMe}$ (cod) and $\mathrm{PPh}_{3}$ (Scheme 2). All complexes were fully characterized by elemental analysis and NMR measurements.

The molecular structures of 1a-1c have been successfully determined by X-ray crystallography. Suitable single crystals of 1a-1c were obtained by crystallization from hot heptane solution. For 1a, there are two independent molecules in a unit cell (see Table 1). Fig. 1a shows the ORTEP drawing for 1a. The palladium atom has a square-planar coordination geometry. The chlorine atom attached to the Pd atom lies trans to the oxygen atom. 
Triphenylphosphine ligand occupies the position trans to the nitrogen due to a steric hindrance between $\mathrm{PPh}_{3}$ ligand and the 2,6-diisopropylphenyl group. Selected bond lengths and bond angles were summarized in Table 2. These bond lengths and bond angles around the palladium atom were comparable to those of analogous palladium complexes [1n, 2b-d]. In the structures of $\mathbf{1 b}$ and $1 \mathbf{c}$ shown in Figs. 1b-1c, each palladium atom has also a square-planar coordination geometry. The $\mathrm{CH}_{3}$ group coordinating to the $\mathrm{Pd}$ atom lies trans to the oxygen atom. $\mathrm{PPh}_{3}$ ligand occupies the position trans to the nitrogen bearing the bulky 2,6-diisopropyl group. Selected bond lengths and bond angles were summarized in Table 3. The $\mathrm{Pd}-\mathrm{C}$ bond length of 1b (2.064(4) ̊) was similar to that of 1c (2.059(5) $\AA$ ) and other $\mathrm{Pd}-\mathrm{C}\left(\mathrm{CH}_{3}\right)$ bond lengths of the complexes bearing salicylaldiminato ligands are in the range between $2.001 \AA$ and $2.046 \AA$ [ $1 \mathrm{n}$, $2 \mathrm{a}-\mathrm{c}]$.

The ${ }^{1} \mathrm{H}$ NMR spectra of $\mathbf{1 a}-\mathbf{1 c}$ in $\mathrm{CDCl}_{3}$ displayed characteristic resonances. Signals corresponding to the methyl protons of the isopropyl moieties on the salicylaldiminato ligand were split into two doublets indicating rotations between the nitrogen and the ipso carbon of 1a-1c were restricted. The ketimine $(H \mathrm{C}=\mathrm{N})$ proton resonances of $\mathbf{1 a}-\mathbf{1 c}$ were displayed as doublets near $8.0 \mathrm{ppm}$ with a phosphorus coupling $\left({ }^{4} J_{\mathrm{PH}}=\mathrm{ca} .12 \mathrm{~Hz}\right)$. These chemical shifts and coupling constants were similar to those observed for analogous complexes [1n, 2b]. As for $\mathbf{1 a}$ and $\mathbf{1 b}$, proton resonances of the hydroxyl moiety were observed at $4.99 \mathrm{ppm}$ (1a) and 5.76 ppm (1b), suggesting an existence of intramolecular hydrogen bond with the oxygen atom coordinating to the palladium [9]. Resonances of the methyl group on the palladium appeared as a doublet at $-0.36 \mathrm{ppm}\left({ }^{3} J_{\mathrm{PH}}=2.98 \mathrm{~Hz}\right)$ for $\mathbf{1 b}$ and $-0.45 \mathrm{ppm}\left({ }^{3} J_{\mathrm{PH}}=2.53 \mathrm{~Hz}\right)$ for $\mathbf{1 c}$, respectively. In ${ }^{13} \mathrm{C}$ NMR, a resonance of the methyl group was observed as a doublet at 0.19 $\operatorname{ppm}\left({ }^{2} J_{\mathrm{PC}}=11.2 \mathrm{~Hz}\right)$ for $\mathbf{1 b}$ and $1.79 \mathrm{ppm}\left({ }^{2} J_{\mathrm{PC}}=11.2 \mathrm{~Hz}\right)$ for $\mathbf{1 c}$. These resonances are similar to other methylpalladium complexes bearing salicylaldiminato ligands $[1 \mathrm{n}] .{ }^{31} \mathrm{P}$ resonances of 1a-1c in $\mathrm{CDCl}_{3}$ appeared at 30.54 ppm, $43.51 \mathrm{ppm}$ and $35.92 \mathrm{ppm}$, respectively.

\subsection{Deprotonation of $\mathbf{1 b}$}

The complex $\mathbf{1 b}$ has the hydroxyl moiety in the close proximity of the palladium center and the hydroxyl functionality can be deprotonated by the addition of a base. In ${ }^{1} \mathrm{H}$ NMR spectrum of 1b in THF- $d_{8}$, a signal at 5.76 ppm attributed to the hydroxyl proton (signal $b$ in Fig. 2a) disappeared on adding 1 equiv of ${ }^{t} \mathrm{BuOK}$ in THF (Fig. 2b). In addition, the signal $a$ assigned to the imino proton $\left(8.08 \mathrm{ppm},{ }^{4} J_{\mathrm{PH}}=10.7 \mathrm{~Hz}\right)$ showed down-field shift to $8.64 \mathrm{ppm}$. The methyl proton resonance of $\mathbf{1 b}$ observed as a doublet peak at $-0.36 \mathrm{ppm}$ (signals $c$ in Fig. 2a) was shifted to $0.12 \mathrm{ppm}\left({ }^{2} J_{\mathrm{PH}}=3.17 \mathrm{~Hz}\right)$ on the deprotonation (Fig. 2b). Other resonances of the 
salicylaldiminato ligand also moved as shown in Fig. $2 \mathrm{~b}$. In addition, a ${ }^{31} \mathrm{P}$ resonance of $\mathbf{1 b}$ at $43.51 \mathrm{ppm}$ was shifted to $36.38 \mathrm{ppm}$ after the addition of ${ }^{t} \mathrm{BuOK}$. Here, no free $\mathrm{PPh}_{3}$ resonance $\left(-4.54 \mathrm{ppm}\right.$ in THF- $\left.d_{8}\right)$ [10] was observed. These clear spectral changes caused with adding ${ }^{t} \mathrm{BuOK}$ was not observed with 1c bearing the methoxyl moiety in place of the hydroxyl group. Notably, $\mathbf{1 b}$ was restored by adding 1 equiv $\mathrm{HCl}$ in $\mathrm{Et}_{2} \mathrm{O}$ to the deprotonated $\mathbf{1 b}$ (from Fig. $2 \mathbf{b}$ to Fig. 2c), indicating the reversible change observed with 1b (Figs. 2a-b) must be due to the deprotonation/protonation of the hydroxyl group on the salicylaldiminato ligand.

\subsection{Polymerization of methyl acrylate}

The polymerization of methyl acrylate was carried out in a mixture of THF and $\mathrm{CH}_{2} \mathrm{Cl}_{2}$ in the presence of a catalytic amount of $\mathbf{1 b}$ or $\mathbf{1 c}(\mathrm{S} / \mathrm{C}=1000)$ at room temperature (Table 3). Employing $\mathbf{1 b}$ as a catalyst, poly(methyl acrylate) was obtained in $79 \%$ yield with a moderate polydispancy (entry 1) [11]. According to ${ }^{1} \mathrm{H}$ and ${ }^{13} \mathrm{C}$ NMR spectra, the polymer thus obtained had atactic microstructures [12]. As a catalyst, 1c showed the comparable result (entry 2). However, effect of the addition of ${ }^{t} \mathrm{BuOK}$ was quite different between $\mathbf{1 b}$ and $\mathbf{1 c}$. The catalytic activity of $\mathbf{1 b}$ in the presence of 1 equiv ${ }^{t} \mathrm{BuOK}$ drastically decreased, giving the corresponding polymer in $19 \%$ yield (entry 4). On the other hand, in the case of $\mathbf{1 c}$ as the catalyst, the reaction was not suppressed by the added ${ }^{t} \mathrm{BuOK}$ (entry 5). These results clearly indicate that the presence of potassium cation close proximity to the palladium center affects the catalytic activity considerably.

\section{Conclusion}

New palladium complexes with salicylaldiminato ligands $(\mathbf{1 a}-\mathbf{1 c})$ were synthesized and their structures were confirmed by X-ray crystallography. A reversible deprotonated/protonation of the hydroxyl group of $\mathbf{1 b}$ was observed. Notably, the introduction of potassium cation in close proximity to the palladium affected the catalytic activity considerably in the polymerization of methyl acrylate.

\section{Appendix A. Supplementary data}

Crystallographic data for complexes 1a-1c have been deposited with the Cambridge Crystallographic Data Centre, CCDC Nos. 786886, 786887, and 786888, respectively. These data can be obtained free of charge from The Cambridge Crystallographic Data Centre via www.ccdc.cam.ac.uk/data_request/cif. 


\section{References}

[1] (a) H. Makio, T. Fujita, Acc. Chem. Res. 42 (2009) 1532; (b) H. Makio, N. Kashiwa, T. Fujita, Adv. Synth. Catal. 344 (2002) 477; (c) V.C. Gibson, S.K. Spitzmesser, Chem. Rev. 103 (2003) 283; (d) T. Matsugi, T. Fujita, Chem. Soc. Rev. 37 (2008) 1264; (e) D.A. Bansleben, S.K. Freiedrich, T.R. Younkin, R.H. Grubbs, C. Wnag, R.T. Li, WO98/03165 (1998); (f) C. Wang, S. Friedrich, T.R. Younkin, R.T. Li, R.H. Grubbs, D.A. Bansleben, M.W. Day, Organometallics 17 (1998) 3150; (g) T.R. Younkin, E.F. Connor, J.I. Henderson, S.K. Friedrich, R.H. Grubbs, D.A. Bansleben, Science 287 (2000) 460; (h) E.F. Connor, T.R. Younkin, J.I. Henderson, A.W. Waltman, R.H. Grubbs. Chem. Commun. (2003) 2272; (i) W.H. Sun, H. Yang, Z. Li, Y. Li, Organometallics 22 (2003) 3678; (j) C. Carlini, A. Macinai, F. Masi, A.M.R. Galletti, R. Santi, G. Sbrana, A. Sommazzi, J. Polym. Sci. A 42 (2004) 2534; (k) C. Carlini, M. Martinelli, A.M.R. Galletti, G. Sbrana. J. Polym. Sci. A 44 (2006) 1514; (1) Q. Chen, J. Yu, J. Huang, Organometallics 26 (2007) 617; (m) M. Delferro, J. P. McInnis, T. J. Marks, Organometallics 29 (2010) 5040; (n) D.J. Darensbourg, C.G. Ortiz, J.C. Yarbrough, Inorg. Chem. 42 (2003) 6915; (1) H. Liang, J. Liu, X. Li, Y. Li, Polyhedron 23 (2004) 1619.

[2] (a) Y. Chen, S. Mandal, A. Sen, Organometallics 29 (2010) 3160; (b) M. Kang, A. Sen, Organometallics 24 (2005) 3508; (c) L.F. Groux, T. Weiss, D.N. Reddy, P.A. Chase, W.E. Piers, T. Ziegler, M. Parvez, J. Benet-Buchholz, J. Am. Chem. Soc. 127 (2005) 1854; (d) T. Hu, Y. G. Li, Y. S. Li, N. H Hu, J. Mol. Catal. A: Chem 253 (2006) 155; (e) K. Ishizaki, S. Washimi, K. Kimura, JP200172654 (1999).

[3] (a) Y. Himeda, N. Onozawa-Komatsuzaki, H. Sugihara, H. Arakawa, K. Kasuga, Organometallics 23 (2004) 1480; (b) S. Haneda, Z. Gan, K. Eda, M. Hayashi, Organometallics 26 (2007) 6551.

[4] W.L.F. Armarego, C.L.L. Chai, Purification of Laboratory Chemicals, 5th ed., Burrerworth-Heinemann, Oxford, 2003.

[5] D. Drew, J.R. Doyle, Inorg. Synth., 13 (1972) 52

[6] R.E. Rülke, J.M. Ernsting, A.L. Spek, C.J. Elsevier, P.W.N.M. van Leeuwen, K. Vrieze, Inorg. Chem. 32 (1993) 5769.

[7] (a) CrystalClear: Rigaku Corporation, 1999. CrystalClear Software User's Guide, Molecular Structure Corporation, Orem, UT, USA, 2000. (b) J.W. Pflugrath, Acta Cryst. D 55 (1999) 1718. 
[8] (a) Crystal Structure Analysis Package, CrystalStructure, ver. 3.6.0., Rigaku and Rigaku/MSC, The Woodlands, TX, 2000-2004; (b) D.J. Watkin, C.K. Prout, J.R. Carruthers, P.W. Betteridge, Chemical Crystallography Laboratory, Oxford, UK, 1996.

[9] The proton resonances of the hydroxyl moiety of 2-hydroxyanisole was observed at 5.64 ppm: K.W. Anderson, T. Ikawa, R.E. Tundel, S.L. Buchwald. J. Am. Chem. Soc. 128 (2006) 10694.

[10] T. Fujihara, S. Yoshida, H. Ohta, Y. Tsuji, Angew. Chem. Int. Ed. 47 (2008) 8310.

[11] The polymerization reaction of entry 1 in Table 3 was completely halted upon the addition of galvinoxyl, suggesting the reaction would proceed via some radical pathway $[2 \mathrm{a}]$.

[12] For analysis of microstructure of poly(methyl acrylate), see: T. Kawamura, N. Toshima, K. Matsuzaki, Macromol. Chem. Phys. 12 (1995) 3415 and references cited therein. 
Table 1

Crystallographic data of $\mathbf{1 a}-\mathbf{1 c}$

\begin{tabular}{|c|c|c|c|}
\hline & $1 \mathbf{a}$ & 1b & 1c \\
\hline empirical formula & $\mathrm{C}_{37} \mathrm{H}_{36} \mathrm{NO}_{2} \mathrm{ClPdP}$ & $\mathrm{C}_{38} \mathrm{H}_{39} \mathrm{NO}_{2} \mathrm{PdP}$ & $\mathrm{C}_{39} \mathrm{H}_{42} \mathrm{NO}_{2} \mathrm{PdP}$ \\
\hline formula weight & 699.52 & 679.11 & 682.05 \\
\hline temp / K & 153 & 153 & 153 \\
\hline crystal system & monoclinic & monoclinic & monoclinic \\
\hline space group & $P 2_{1} / \mathrm{c}(\# 14)$ & $P 2_{1} / \mathrm{c}(\# 14)$ & $P 2_{1} / \mathrm{n}(\# 14)$ \\
\hline$a / \AA$ & $20.286(5)$ & $14.422(3)$ & $11.423(4)$ \\
\hline$b / \AA$ & $11.491(2)$ & $11.035(2)$ & $24.228(7)$ \\
\hline$c / \AA$ & $29.737(7)$ & $21.495(5)$ & $12.344(4)$ \\
\hline$\beta / \operatorname{deg}$ & $107.427(3)$ & $105.888(3)$ & $100.144(5)$ \\
\hline$V / \AA^{3}$ & 6613(3) & $3290(1)$ & $3363(1)$ \\
\hline$Z$ & 8 & 4 & 4 \\
\hline$\rho_{\text {cacd }} / \mathrm{g} \mathrm{cm}^{-3}$ & 1.405 & 1.371 & 1.371 \\
\hline unique reflections & $14825\left(\mathrm{R}_{\mathrm{int}}=0.092\right)$ & $7224\left(\mathrm{R}_{\mathrm{int}}=0.064\right)$ & $7444\left(\mathrm{R}_{\mathrm{int}}=0.085\right)$ \\
\hline observed reflections & 14825 (all data) & 7224 (all data) & 7444 (all data) \\
\hline GOF & 1.025 & 1.010 & 1.047 \\
\hline $\begin{array}{l}R 1(I>2 \sigma(I))^{\mathrm{a}} \\
w R 2(\text { all data })^{\mathrm{a}}\end{array}$ & $0.055,0.141^{\mathrm{b}}$ & $0.047,0.095^{\mathrm{c}}$ & $0.059,0.131^{\mathrm{d}}$ \\
\hline
\end{tabular}




\section{Table 2}

Selected bond lengths ( $\AA$ ) and angles (deg) for 1a

\begin{tabular}{lll}
\hline & 1a (complex A) & 1a (complex B) \\
\hline Pd-Cl & $2.2671(11)$ & $2.2817(14)$ \\
Pd-N & $2.074(4)$ & $2.2454(14)$ \\
Pd-P & $2.2513(14)$ & $2.073(4)$ \\
Pd-O & $2.005(3)$ & $2.001(3)$ \\
& & \\
Cl-Pd-N & $91.53(11)$ & $93.49(12)$ \\
Cl-Pd-O & $175.01(10)$ & $175.33(10)$ \\
Cl-Pd-P & $85.87(4)$ & $84.32(4)$ \\
N-Pd-O & $91.64(14)$ & $91.01(15)$ \\
N-Pd-P & $174.03(12)$ & $177.80(12)$ \\
O-Pd-P & $91.33(10)$ & $91.18(10)$ \\
\hline
\end{tabular}

\section{Table 3}

Selected bond lengths $(\AA)$ and angles (deg) for $\mathbf{1 b}$ and $\mathbf{1 c}$

\begin{tabular}{lll}
\hline & $\mathbf{1 b}$ & $\mathbf{1 c}$ \\
\hline $\mathrm{Pd}-\mathrm{C}(1)$ & $2.064(4)$ & $2.059(5)$ \\
$\mathrm{Pd}-\mathrm{N}(1)$ & $2.095(2)$ & $2.096(4)$ \\
$\mathrm{Pd}-\mathrm{P}(1)$ & $2.2265(8)$ & $2.2620(16)$ \\
$\mathrm{Pd}-\mathrm{O}(1)$ & $2.099(2)$ & $2.100(3)$ \\
& & \\
$\mathrm{C}(1)-\mathrm{Pd}(1)-\mathrm{N}(1)$ & $92.03(13)$ & $90.99(19)$ \\
$\mathrm{C}(1)-\mathrm{Pd}(1)-\mathrm{O}(1)$ & $173.72(11)$ & $176.50(19)$ \\
$\mathrm{C}(1)-\mathrm{Pd}(1)-\mathrm{P}(1)$ & $84.08(10)$ & $83.58(16)$ \\
$\mathrm{N}(1)-\mathrm{Pd}(1)-\mathrm{O}(1)$ & $89.27(11)$ & $88.45(16)$ \\
$\mathrm{N}(1)-\mathrm{Pd}(1)-\mathrm{P}(1)$ & $175.48(9)$ & $174.18(12)$ \\
$\mathrm{O}(1)-\mathrm{Pd}(1)-\mathrm{P}(1)$ & $94.84(7)$ & $97.09(11)$ \\
\hline
\end{tabular}




\section{Table 3}

Palladium-catalyzed polymerization of methyl acrylate ${ }^{\mathrm{a}}$

\begin{tabular}{cccccc}
\hline entry & catalyst & additive & Yield $(\%)$ & $M \mathrm{n}\left(\times 10^{-3}\right)^{\mathrm{b}}$ & PDI $^{\mathrm{b}}$ \\
\hline 1 & $\mathbf{1 b}$ & none & 79 & 116 & 2.30 \\
2 & $\mathbf{1 c}$ & none & 70 & 114 & 2.13 \\
3 & $\mathbf{1 b}$ & ${ }^{t} \mathrm{BuOK}^{\mathrm{c}}$ & 19 & 129 & 1.84 \\
4 & $\mathbf{1 c}$ & ${ }^{t} \mathrm{BuOK}^{\mathrm{c}}$ & 70 & 135 & 1.94
\end{tabular}

a Conditions: methyl acylate $(1.0 \mathrm{~mL}, 12 \mathrm{mmol}), 1(0.011 \mathrm{mmol}, \mathrm{S} / \mathrm{C}=1000)$, $\mathrm{THF} / \mathrm{CH}_{2} \mathrm{Cl}_{2}=0.3 \mathrm{~mL} / 3.6 \mathrm{~mL}, \mathrm{RT}, 24 \mathrm{~h} .{ }^{\mathrm{b}}$ Determined by analytical SEC using polystyrenes as a standard. ${ }^{\mathrm{c} t} \mathrm{BuOK}(1.0 \mathrm{M}$ solution in THF, $0.011 \mathrm{mmol})$ was used. 
(a)

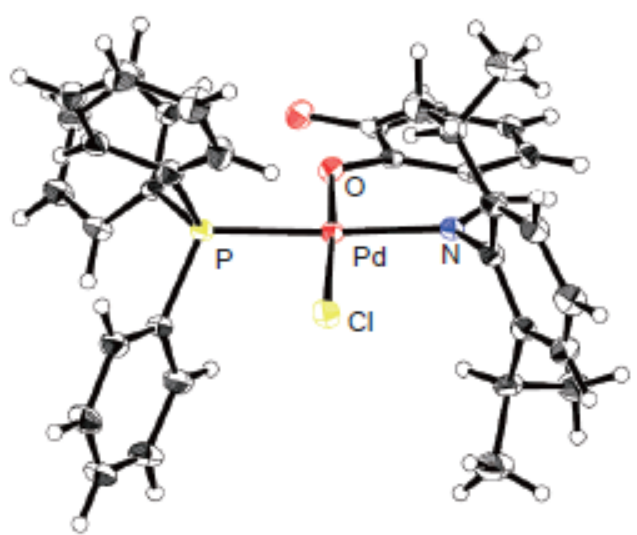

(b)

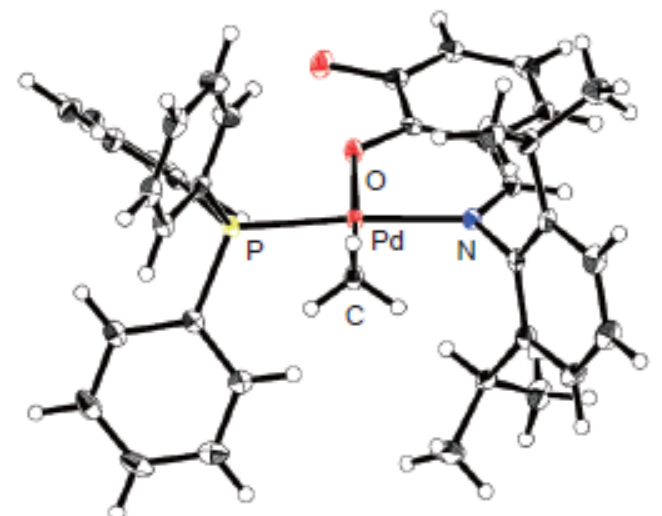

(c)

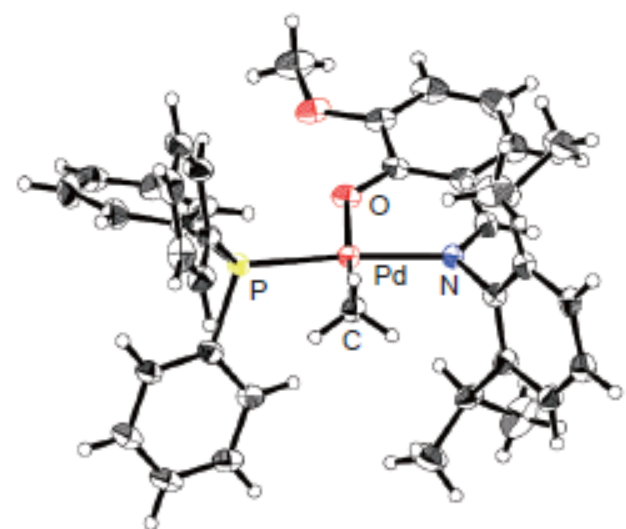

Fig. 1. ORTEP drawings of (a) 1a, (b) $\mathbf{1 b}$ and (c) 1c with thermal ellipsoids at $30 \%$ probability levels. 


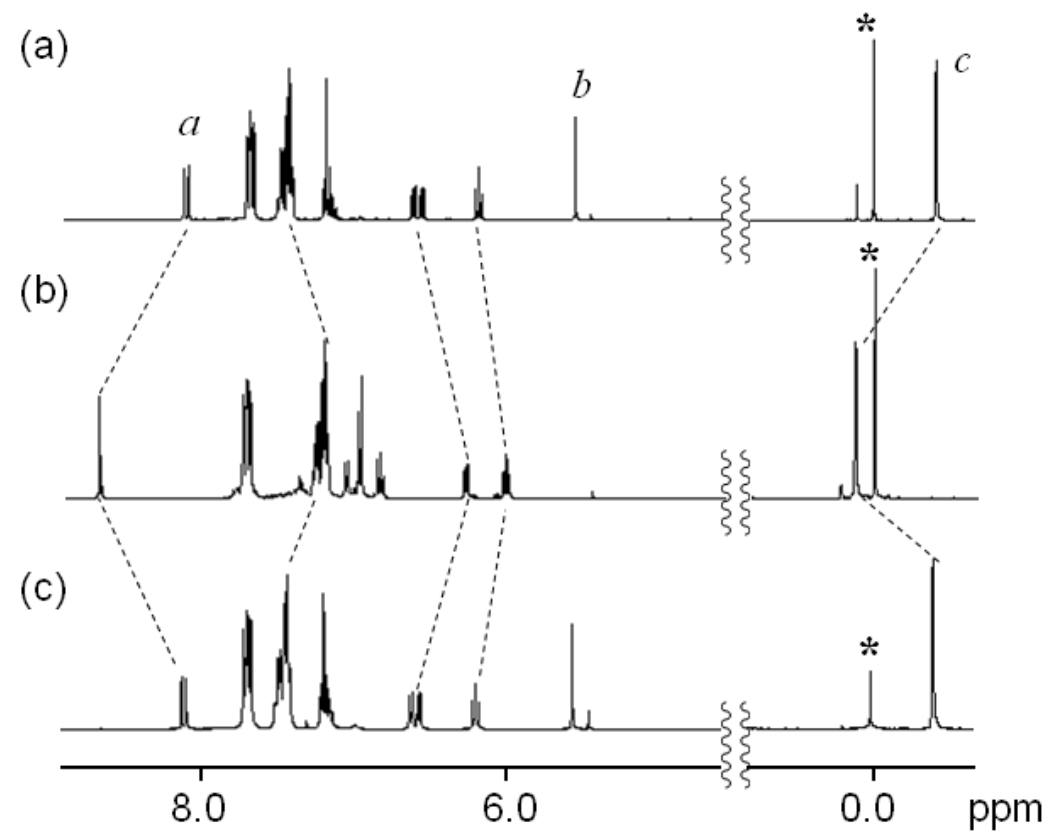

Fig. 2. ${ }^{1} \mathrm{H}$ NMR spectra of (a) $\mathbf{1 b}$ in THF- $d_{8}$, (b) after the addition of 1 equiv ${ }^{t} \mathrm{BuOK}$ in THF, and (c) after further addition of 1 equiv $\mathrm{HCl}$ in $\mathrm{Et}_{2} \mathrm{O}$. * indicates TMS.

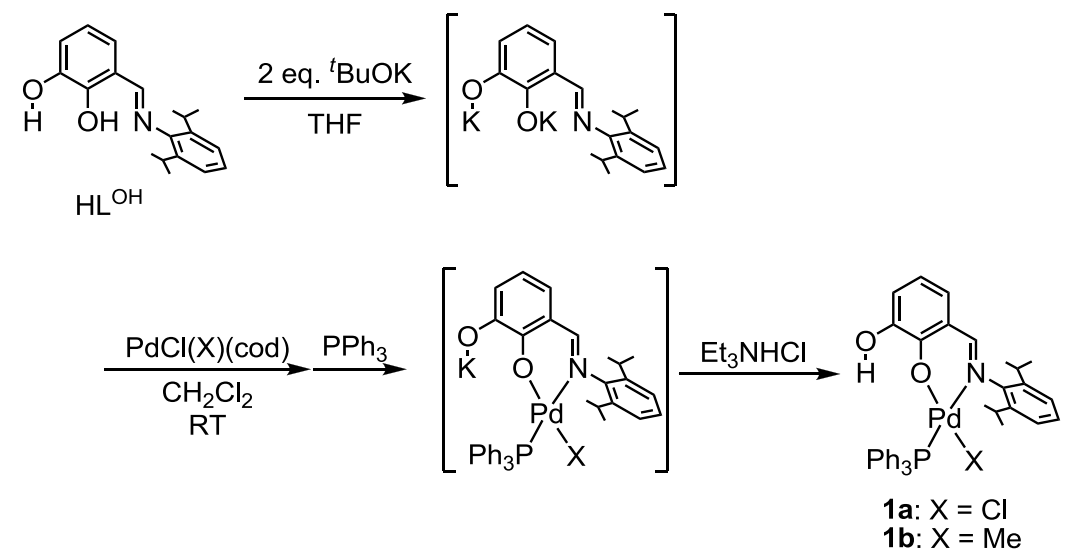

\section{Scheme 1}

Synthesis of palladium complexes $\mathbf{1 a}$ and $\mathbf{1 b}$.

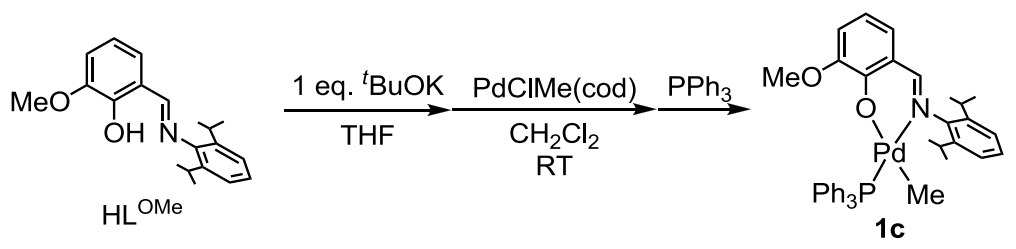

\section{Scheme 2}

Synthesis of a palladium complex $\mathbf{1 c}$. 